\title{
Mathematical simulation of hydrogen production via methanol steam reforming using double-jacketed membrane reactor
}

\author{
Chi-Hua Fu, Jeffrey C.S. Wu* \\ Department of Chemical Engineering, National Taiwan University, Taipei 10617, Taiwan ROC
}

Received 20 November 2006; received in revised form 30 May 2007; accepted 16 July 2007

Available online 4 September 2007

\begin{abstract}
The hydrogen production and purification via methanol reforming reaction was studied in a double-jacketed Pd membrane reactor using a 1-D, non-isothermal mathematical model. Both mass and heat transfer behavior were evaluated simultaneously in three parts of the reactor, annular side, permeation tube and the oxidation side. The simulation results exhibited that increasing the volumetric flow rate of hydrogen in permeation side could enhance hydrogen permeation rate across the membrane. The optimum velocity ratio between permeation and annular sides is 10 . However, hydrogen removal could lower the temperature in the reformer. The hydrogen production rate increases as temperature increases at a given Damköhler number, but the methanol conversion and hydrogen recovery yield decrease. In addition, the optimum molar ratio of air and methanol was 1.3 with three air inlet temperatures. The performance of a double-jacketed membrane reactor was compared with an autothermal reactor by judging against methanol conversion, hydrogen recovery yield and production rate. Under the same reaction conditions, the double-jacketed reactor can convert more methanol at a given reactor volume than that of an autothermal reactor.

(C) 2007 International Association for Hydrogen Energy. Published by Elsevier Ltd. All rights reserved.
\end{abstract}

Keywords: Double-jacketed membrane reactor; Methanol steam reforming; Autothermal membrane reactor; Mathematical model

\section{Introduction}

The application of membrane reactor on hydrogen production has attracted much attention in the recent years [1-6]. The integration of reaction and purification has advantages in medium or small scale power usage. In addition, products removal simultaneously by membrane can overcome the constraint of thermodynamic equilibrium to higher conversion. Therefore, a membrane reactor is advantageous for higher conversion or lower reaction temperature. Steam reforming reaction is one of the potential applications for membrane reactor. A supported palladium $(\mathrm{Pd})$ membrane can promote the endothermic reaction to higher conversion compared with a conventional reactor at the same temperature.

Methanol is usually used as hydrogen source in steam reforming reaction. Liquid methanol is easy to store and transport at room temperature. Furthermore, methanol has high hydrogen-carbon ratio and absence of carbon-carbon bonds.

\footnotetext{
* Corresponding author. Tel.: +886223631994; fax: +886223623040.

E-mail address: cswu@ntu.edu.tw (J.C.S. Wu).
}

The overall reaction can be expressed in

$$
\mathrm{CH}_{3} \mathrm{OH}+\mathrm{H}_{2} \mathrm{O} \rightarrow \mathrm{CO}_{2}+3 \mathrm{H}_{2}, \quad \Delta H_{298 \mathrm{~K}}=49 \mathrm{KJ} / \mathrm{mol} \text {. }
$$

Methanol steam reforming mechanisms over copper based catalyst have been developed in the past decades. Jiang et al. proposed an empirical power rate equation over a $\mathrm{CuO} / \mathrm{ZnO} / \mathrm{Al}_{2} \mathrm{O}_{3}$ catalyst at temperature from 443 to $533 \mathrm{~K}$ $[7,8]$. The main products were hydrogen and carbon dioxide in the ratio of three, with small amount of dimethyl ether and carbon monoxide. Detailed kinetic study showed that methanol dehydrogenation is the rate-determining step of the steam reforming reaction. Peppley et al. studied the surface mechanism based on three overall reactions (methanol steam reforming, water gas shift reaction, and methanol decomposition) $[9,10]$. They claimed that methanol decomposition occurred on different types of active sites than the other two reactions and was the slowest reaction among the three reactions.

Palladium is one of the best materials for metallic membrane due to its excellent permselectivity of hydrogen. Many literatures have been reported in the permeating mechanism of hydrogen over Pd membrane, [11-13]. In the recent years, 


\begin{tabular}{|c|c|c|c|}
\hline \multicolumn{4}{|c|}{ Nomenclature } \\
\hline$A_{1}$ & $\begin{array}{l}\text { heat transfer area between annular and } \\
\text { oxidation side, } \mathrm{m}^{2}\end{array}$ & $\begin{array}{l}r_{\text {methanol }} \\
S\end{array}$ & $\begin{array}{l}\text { reaction rate of methanol reforming, } \mathrm{mol} / \mathrm{m}^{3} \mathrm{~s} \\
\text { external surface area of pellet, } \mathrm{m}^{2}\end{array}$ \\
\hline$A_{2}$ & $\begin{array}{l}\text { heat transfer area between annular and } \\
\text { permeation side } \mathrm{m}^{2}\end{array}$ & $T$ & temperature, $\mathrm{K}$ \\
\hline$A_{\text {mem }}$ & $\begin{array}{l}\text { permeation side, } \mathrm{m}^{2} \\
\text { permeation area per unit volume, } \mathrm{m}^{2} / \mathrm{m}^{3}\end{array}$ & $U_{1}$ & $\begin{array}{l}\text { overall heat transfer coefficient between annular } \\
\text { and oxidation side, } \mathrm{W} / \mathrm{m}^{2} \mathrm{~K}\end{array}$ \\
\hline $\begin{array}{l}C_{i} \\
C p\end{array}$ & $\begin{array}{l}\text { concentration of } i \text { species, } \mathrm{mol} / \mathrm{m}^{3} \\
\text { average heat capacity, } \mathrm{J} / \mathrm{m} \mathrm{K}\end{array}$ & $U_{2}$ & $\begin{array}{l}\text { overall heat transfer coefficient between annular } \\
\text { and permeation side, } \mathrm{W} / \mathrm{m}^{2} \mathrm{~K}\end{array}$ \\
\hline$C_{\mathrm{s}}$ & $\begin{array}{l}\text { concentration on the catalyst surface, } \\
\mathrm{mol} / \mathrm{m}^{3}\end{array}$ & $\begin{array}{l}u \\
V\end{array}$ & $\begin{array}{l}\text { superficial velocity, } \mathrm{m} \\
\text { pellet volume, } \mathrm{m}^{3}\end{array}$ \\
\hline$D a$ & Damköhler number (defined in Eq. (16)) & $z$ & axial coordinate of reactor, $\mathrm{m}$ \\
\hline$D e$ & effectiveness factor & $\Delta H_{\text {oxi }}$ & enthalpy of oxidation reaction, $\mathrm{J} / \mathrm{mol}$ \\
\hline$d_{\mathrm{mem}}$ & membrane thickness, $\mathrm{m}$ & $\Delta H_{\mathrm{ref}}$ & enthalpy of reforming reaction, $\mathrm{J} / \mathrm{mol}$ \\
\hline $\begin{array}{l}d_{\mathrm{p}} \\
d_{\mathrm{t}}\end{array}$ & $\begin{array}{l}\text { pellet diameter, } \mathrm{m} \\
\text { reformer diameter, } \mathrm{m}\end{array}$ & \multicolumn{2}{|l|}{ Greek letters } \\
\hline $\begin{array}{l}E a \\
G_{\text {methanol, } 0}\end{array}$ & $\begin{array}{l}\text { activation energy, } \mathrm{J} / \mathrm{mol} \\
\text { methanol molar rate at the entrance, } \mathrm{mol} / \mathrm{s}\end{array}$ & $\beta$ & 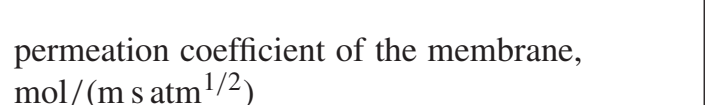 \\
\hline$k_{0}$ & $\begin{array}{l}\text { frequency factor of reforming reaction, } \\
\mathrm{mol} /\left(\mathrm{kg} \mathrm{s} \mathrm{kPa}^{-0.296}\right)\end{array}$ & $\begin{array}{l}\delta \\
\rho_{\mathrm{B}}\end{array}$ & $\begin{array}{l}\text { stoichiometric number of } i \text { or } j \text { species } \\
\text { catalyst density, } \mathrm{kg} / \mathrm{m}^{3}\end{array}$ \\
\hline$L$ & reactor length, $\mathrm{m}$ & $\begin{array}{l}\rho_{\mathrm{B}} \\
\rho_{\mathrm{g}}\end{array}$ & gas density, $\mathrm{kg} / \mathrm{m}^{3}$ \\
\hline $\begin{array}{l}N \\
n\end{array}$ & $\begin{array}{l}\text { molar flux, } \mathrm{mol} /\left(\mathrm{m}^{2} \mathrm{~s}\right) \\
\text { reaction order }\end{array}$ & $\phi$ & generalized Thiele modulus \\
\hline $\begin{array}{l}P e_{\mathrm{m}} \\
\text { Per }\end{array}$ & $\begin{array}{l}\text { Peclet number for mass transfer } \\
\text { dimensionless permeation rate (defined in }\end{array}$ & Subscripts & \\
\hline & Eq. (17)) & $i$ & component number in annular side \\
\hline$P_{i}$ & partial pressure of $i$ species, $\mathrm{kPa}$ & $j$ & component number in oxidation side \\
\hline$R$ & ideal gas constant, atm L/(mol K) & $\mathrm{o}$ & oxidation \\
\hline$R_{\mathrm{A} / \mathrm{M}}$ & molar ratio between air and methanol & obs & observed \\
\hline$R_{\mathrm{W} / \mathrm{M}}$ & molar ratio between water and methanol & $\mathrm{p}$ & permeation \\
\hline$r_{i}$ & reaction rate of $i$ species, $\mathrm{mol} / \mathrm{m}^{3} \mathrm{~s}$ & $\mathrm{r}$ & reforming \\
\hline
\end{tabular}

many researches have been focused on the application of Pd membrane reactor. However, steam reforming reaction is an endothermic process; external heat is needed to maintain the overall energy balance. Lin and Rei used a double-jacketed reactor for the endothermic reaction [14-16]. Un-reacted methanol and un-permeated hydrogen were oxidized to supply the energy required for steam reforming. The double-jacketed membrane reactor system can be operated under self-energy balanced condition. They also concluded that the production flux of hydrogen was mainly controlled by the ratio of methanol inlet flow rate and the surface area of membrane, and WHSV. Lindstrom and Pettersson [17] used a similar strategy in fuel cell applications and concluded that the optimal setting of oxygen to methanol ratio was 0.15 , which resulted in a reactor temperature of $260^{\circ} \mathrm{C}$.

Another process is to feed a mixture of air, steam, and fuel in a single reactor, in which partial oxidation and steam reforming take place in one system. The system can be operated under a thermal balanced condition, or so-called autothermal reaction, by adjusting the molar ratio of air-fuel and steam-fuel [18-22]. The ideal overall reaction of the methanol autothermal reaction is shown as

$$
\begin{gathered}
4 \mathrm{CH}_{3} \mathrm{OH}+3 \mathrm{H}_{2} \mathrm{O}+\frac{1}{2} \mathrm{O}_{2} \rightarrow 4 \mathrm{CO}_{2}+11 \mathrm{H}_{2}, \\
\Delta H_{573 \mathrm{~K}}=0 \mathrm{KJ} / \mathrm{mol} .
\end{gathered}
$$

The advantages of autothermal reactor are simple reactor design, less heat transfer resistance, and fast start-up time. Extensive researches of catalyst modification [23-25], fuels [26-28], process design [28-31], and simulation models [32-35] have been studied using an autothermal reactor. However, it is difficult to manipulate the optimal addition of oxygen under zero reaction enthalpy condition, that is, too much oxygen can lead to the total oxidation of methanol or even oxidized part of hydrogen. On the other hand, too little oxygen results in lower methanol conversion. Most importantly, it is hard to find a catalyst with both good reforming and oxidation abilities.

Many studies of membrane reactor have focused on establishing the mathematical model. Harold et al. proposed an isothermal one-dimensional model of palladium supported membrane reactor, considering methanol direct decomposition (over $\mathrm{Pd} / \mathrm{SiO}_{2}$ catalyst), methanol steam reforming (over $\mathrm{Cu} / \mathrm{ZnO} / \mathrm{Al}_{2} \mathrm{O}_{3}$ catalyst), and methanol partial oxidation 
(over $\mathrm{Cu} / \mathrm{Al}_{2} \mathrm{O}_{3}$ catalyst) [36]. Ji et al. studied the simulation of methane steam reforming membrane reactor, considering the material and energy balance of both gas (reactants and products) and solid (catalyst) phases [37]. Fukuhara et al. proposed a two-dimensional model of a membrane reactor of dehydrogenation of ethylbenzene, in which both material and energy balance were considered [38]. So far, methanol reforming in a double-jacketed membrane reactor has been studied by computer simulation with fixed amount of methanol feeding $[35,39,40]$. However, the simulation of a self-energy balanced double-jacketed reactor with exhausted effluents as the combustion reactants has not been studied. The optimum hydrogen production under a wide range of operation conditions thus is still unclear.

The objective of this study is to simulate the double-jacketed membrane reactor of methanol steam reforming reaction by using a one-dimensional model; both mass and energy balances are considered. The methanol conversion, hydrogen recovery yield and production rate are analyzed by considering reaction rate, convection rate, and permeation rate. In addition, the double-jacketed membrane reactor and autothermal membrane reactor in methanol steam reforming are evaluated by the conversion of methanol, the recovery yield and production rate of hydrogen.

\section{Mathematical model}

Fig. 1 shows the schematic diagram of the double-jacketed membrane reactor. Reactants flow into the annular side packed with catalysts, and hydrogen from reforming side permeates across the palladium membrane. The un-reacted effluents flow into the oxidized zone, mixed with air, where the heat supplies the steam reforming reaction.

The mathematical model of membrane reactor with materials and energy balance is established based on the following assumptions:

(1) The mass and heat diffusion in the $z$-axis direction can be neglected.

(2) The radial mass and heat gradient can be neglected based on plug flow reactor behavior.

(3) Physical properties such as heat capacity, gas density, and heat transfer coefficient are constants with temperature variation.

(4) The intra-particle diffusion of reactants on catalysts can be neglected.

(5) The system is well insulated such that no heat exchanges take place with the surroundings.

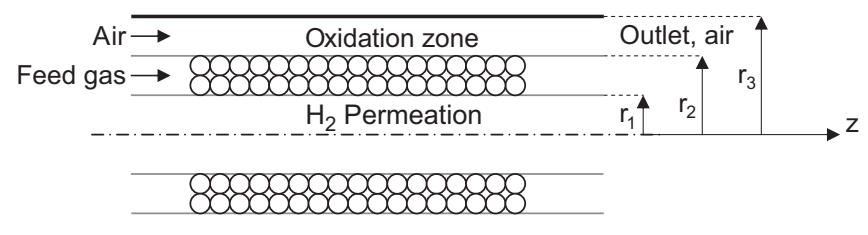

Fig. 1. Schematic diagram of double-jacketed membrane reactor.
(6) There is no temperature difference between fluid and catalyst particles.

(7) The effectiveness factor is assumed to be one.

The effectiveness factor is assumed to be one based on a rough estimation. When Reynolds' number is larger than 100, the Peclet number for mass transfer is usually in the order of 1 while the reformer diameter is much larger than the pellet diameter [41], which is evaluated using Eq. (3). The effective diffusivity is further estimated based on Eq. (4), and is about $10^{-6} \mathrm{~m}^{2} / \mathrm{s}$ in this study. Based on the result in Eq. (4), the generalized Thiele modulus is determined using Eq. (5) [42] and is in the range of $0.1-10$, which is dependent on the concentration of hydrogen and reaction temperature. Therefore it is reasonable to assume a unity effectiveness factor and the reaction is running under kinetic limited region.

$$
\begin{aligned}
& P e_{\mathrm{m}}=8.0\left[1+19.4\left(d_{\mathrm{p}} / d_{\mathrm{t}}\right)^{2}\right], \\
& D e=\frac{d_{\mathrm{p}} u}{P e_{\mathrm{m}}}, \\
& \phi=\frac{V}{S} \frac{\rho_{\mathrm{B}} r_{\text {methanol }}}{\sqrt{2}}\left[\int_{0}^{C_{\mathrm{s}}} \rho_{\mathrm{B}} \cdot D e \cdot r_{\text {methanol }}\left(C_{\mathrm{s}}^{\prime}\right) \mathrm{d} C_{\mathrm{s}}^{\prime}\right]^{-1 / 2} .
\end{aligned}
$$

\subsection{Governing equation and boundary conditions}

\subsubsection{The reaction side}

Mass balance:

$u_{\mathrm{r}} \frac{\mathrm{d} C_{i}}{\mathrm{~d} z}=\delta_{i} \rho_{\mathrm{B}, \mathrm{r}}\left(-r_{i}\right)$

( $i=$ methanol, steam, carbon dioxide),

$u_{\mathrm{r}} \frac{\mathrm{d} C_{\mathrm{H}_{2}}}{\mathrm{~d} z}=3 \rho_{\mathrm{B}, \mathrm{r}}\left(-r_{\text {methanol }}\right)$

$$
-\frac{\beta}{d_{\text {mem }}} A_{\text {mem }}\left(\sqrt{P_{\mathrm{H}_{2}, \mathrm{r}}}-\sqrt{P_{\mathrm{H}_{2}, \mathrm{p}}}\right) \text {. }
$$

Energy balance:

$$
\begin{aligned}
\rho_{\mathrm{g}, \mathrm{r}} C p_{\mathrm{r}} u_{\mathrm{r}} \frac{\mathrm{d} T_{\mathrm{r}}}{\mathrm{d} z}= & \rho_{\mathrm{B}, \mathrm{r}}\left(-r_{\text {methanol }}\right) \Delta H_{\mathrm{ref}}+U_{1} A_{1}\left(T_{\mathrm{o}}-T_{\mathrm{r}}\right) \\
& -U_{2} A_{2}\left(T_{\mathrm{r}}-T_{\mathrm{p}}\right),
\end{aligned}
$$

the boundary condition is

$z=0, \quad C_{\text {methanol }}=C_{\text {methanol }, 0}, \quad C_{\text {steam }}=C_{\text {steam }, 0}$,

$C_{\mathrm{H}_{2}}=0, \quad C_{\mathrm{CO}_{2}}=0, \quad T_{\mathrm{r}}=T_{\mathrm{r}, 0}$

\subsubsection{The permeation side}

Mass balance:

$u_{\mathrm{p}} \frac{\mathrm{d} C_{\mathrm{H}_{2}}}{\mathrm{~d} z}=\frac{\beta}{d_{\mathrm{mem}}} A_{\mathrm{mem}}\left(\sqrt{P_{\mathrm{H}_{2}, \mathrm{r}}}-\sqrt{P_{\mathrm{H}_{2}, \mathrm{p}}}\right)$.

Energy balance:

$\rho_{\mathrm{g}, \mathrm{p}} C p_{\mathrm{p}} u_{\mathrm{p}} \frac{\mathrm{d} T_{\mathrm{p}}}{\mathrm{d} z}=\left(N_{\mathrm{H}_{2}} C p_{\mathrm{H}_{2}}+U_{2} A_{2}\right)\left(T_{\mathrm{r}}-T_{\mathrm{p}}\right)$.

the boundary condition is

$z=0, \quad C_{\mathrm{H}_{2}}=0, \quad T_{\mathrm{p}}=T_{\mathrm{p}, 0}$. 
Table 1

Dimensionless form of simulation model

Reaction side

Material balance

$\frac{\mathrm{d} C_{i}^{*}}{\mathrm{~d} z^{*}}=\frac{\delta_{i} \rho_{\mathrm{B}, \mathrm{r}} L}{u_{\mathrm{r}} C_{\text {methanol }, 0}}\left(-r_{i}\right)(i=$ methanol, steam, carbon dioxide $)$,

$\frac{\mathrm{d} C_{\mathrm{H}_{2}}^{*}}{\mathrm{~d} z^{*}}=\frac{\delta_{\mathrm{H}_{2}} \cdot \rho_{\mathrm{B}, \mathrm{r}} L}{u_{\mathrm{r}} C_{\text {methanol }, 0}}\left(-r_{i}\right)-\frac{\beta L}{u_{\mathrm{r}} d_{\mathrm{mem}} C_{\text {methanol }, 0}} A_{\mathrm{mem}}\left(\sqrt{P_{\mathrm{H}_{2, \mathrm{r}}}}-\sqrt{P_{\mathrm{H}_{2, \mathrm{p}}}}\right)$.

Energy balance

$$
\begin{aligned}
\frac{\mathrm{d} T_{\mathrm{r}}^{*}}{\mathrm{~d} z^{*}}= & -\frac{\rho_{\mathrm{B}, \mathrm{r}} L}{u_{\mathrm{r}} \rho_{\mathrm{g}, \mathrm{r}} C p_{\mathrm{r}} T_{\mathrm{r}, 0}}\left(-r_{i}\right) \Delta H_{\mathrm{ref}}+\frac{U_{1} A_{1} L}{u_{\mathrm{r}} \rho_{\mathrm{g}, \mathrm{r}} C p_{\mathrm{r}}}\left(T_{\mathrm{o}}^{*}-T_{\mathrm{r}}^{*}\right) \\
& -\frac{U_{2} A_{2} L}{u_{\mathrm{r}} \rho_{\mathrm{g}, \mathrm{r}} C p_{\mathrm{r}}}\left(T_{\mathrm{r}}^{*}-T_{\mathrm{p}}^{*}\right) .
\end{aligned}
$$

Boundary conditions

$z^{*}=0, C_{\text {methanol }}=1, C_{\text {steam }}=R_{\mathrm{W} / \mathrm{M}}, C_{\mathrm{H}_{2}}=0, C_{\mathrm{CO}_{2}}=0, T_{\mathrm{r}}=1$.

Permeation side

Material balance

$\frac{\mathrm{d} C_{\mathrm{H}_{2}}^{*}}{\mathrm{~d} z^{*}}=\frac{\beta L}{u_{\mathrm{p}} d_{\mathrm{mem}} C_{\text {methanol, } 0}} A_{\mathrm{mem}}\left(\sqrt{P_{\mathrm{H}_{2, \mathrm{r}}}}-\sqrt{P_{\mathrm{H}_{2, \mathrm{p}}}}\right)$.

Energy balance

$\frac{\mathrm{d} T_{\mathrm{p}}^{*}}{\mathrm{~d} z^{*}}=\frac{\left(N_{\mathrm{H}_{2}} C p_{\mathrm{H}_{2}}+U_{2} A_{2}\right) L}{u_{\mathrm{p}} \rho_{\mathrm{g}, \mathrm{p}} C p_{\mathrm{p}}}\left(T_{\mathrm{r}}^{*}-T_{\mathrm{p}}^{*}\right)$.

Boundary conditions

$z^{*}=0, C_{\mathrm{H}_{2}}^{*}=0, T_{\mathrm{p}}^{*}=T_{\mathrm{p}, 0}^{*}$.

Oxidation zone

$\frac{\mathrm{d}_{j}^{*}}{\mathrm{~d} z^{*}}=\frac{\delta_{j} \rho_{\mathrm{B}, \mathrm{o}} L}{u_{\mathrm{o}} C_{\text {methanol }, 0}}\left(-r_{j}\right)(j=$ methanol, steam, hydrogen, carbon dioxide, oxygen, nitrogen),

$\frac{\mathrm{d} T_{\mathrm{o}}^{*}}{\mathrm{~d} z^{*}}=-\frac{\rho_{\mathrm{B}, \mathrm{o}} L}{u_{\mathrm{o}} \rho_{\mathrm{g}, \mathrm{o}} C p_{\mathrm{o}} T_{\mathrm{r}, 0}}\left(-r_{j}\right) \Delta H_{\mathrm{oxi}}-\frac{U_{1} A_{1} L}{u_{\mathrm{o}} \rho_{\mathrm{g}, \mathrm{o}} C p_{\mathrm{o}}}\left(T_{\mathrm{o}}^{*}-T_{\mathrm{r}}^{*}\right)$.

Boundary conditions

$z^{*}=0, C_{\text {methanol }}^{*}=C_{\text {methanol,guess }}^{*}, C_{\mathrm{H}_{2}}^{*}=C_{\mathrm{H}_{2}, \text { guess }}^{*}, C_{\text {steam }}^{*}=C_{\text {steam,guess }}^{*}$,

$C_{\mathrm{CO}_{2}}^{*}=C_{\mathrm{CO}_{2}, \text { guess }}^{*}, C_{\mathrm{O}_{2}}^{*}=0.2 R_{\mathrm{A} / \mathrm{M}}, T_{\mathrm{o}}^{*}=T_{\mathrm{o}, \text { guess }}^{*}$.

\subsubsection{The oxidation zone}

In the oxidation zone, un-reacted effluent containing methanol and hydrogen is completely oxidized by air to supply thermal energy of the endothermic reforming.

Mass balance:

$u_{\mathrm{o}} \frac{\mathrm{d} C_{j}}{\mathrm{~d} z}=\delta_{j} \rho_{\mathrm{B}, \mathrm{o}}\left(-r_{j}\right)$

( $j=$ methanol, steam, hydrogen, carbon dioxide,

oxygen, nitrogen).
Energy balance:

$\rho_{\mathrm{g}, \mathrm{o}} C p_{\mathrm{o}} u_{\mathrm{o}} \frac{\mathrm{d} T_{\mathrm{o}}}{\mathrm{d} z}=\rho_{\mathrm{B}, \mathrm{o}}\left(-r_{j}\right) \Delta H_{\mathrm{oxi}, \mathrm{j}}-U_{1} A_{1}\left(T_{\mathrm{o}}-T_{\mathrm{r}}\right)$,

the boundary condition is

$z=0, \quad C_{j}=C_{j, \text { guess }}, \quad T_{\mathrm{o}}=T_{\text {guess }}$.

\subsection{Dimensionless analysis}

To simplify the physical interpretation, some dependent and independent variables are converted to dimensionless groups based on Eq. (16). Table 1 lists the dimensionless form of Eqs. (6)-(15).

$z^{*}=\frac{z}{L}, \quad C_{i}^{*}=\frac{C_{i}}{C_{\text {methanol }, 0}}, \quad T^{*}=\frac{T}{T_{\mathrm{r}, 0}}$.

The model is based on an empirical rate expression derived by Jiang et al. using $\mathrm{CuO} / \mathrm{ZnO} / \mathrm{Al}_{2} \mathrm{O}_{3}$ at temperature ranging from 443 to $533 \mathrm{~K}[7,8]$. This kinetic model is divided into two regions. When the partial pressure of hydrogen is less than $7 \mathrm{kPa}$, the rate is proportional to partial pressure of methanol with order of 0.26 , and steam partial pressure with order of 0.03 . The rate equation is changed to hydrogen partial pressure with order of -0.2 when hydrogen partial pressure is larger than $7 \mathrm{kPa}$. The hydrogen permeation over $\mathrm{Pd}-\mathrm{Ag}$ membrane is expressed by Sievert's Law; the permeation equation and the permeation coefficient are listed in Table 2. The dimensions of double-jacketed membrane reactor, the activation energy and enthalpies of reactions and overall heat transfer coefficients are summarized in Table 3.

\section{Result and discussion}

\subsection{Comparison of experimental data and simulation result}

The simulation result was firstly confirmed with the experimental data of a $\mathrm{Pd}$ membrane reactor from Pan [43]. A membrane reactor loaded with catalysts $\mathrm{CuO} / \mathrm{ZnO} / \mathrm{Al}_{2} \mathrm{O}_{3}$ was simulated to compare with Pan's result based on the governing equation listed in Table 1 and the chemical and physical parameters listed in Tables 2 and 3. Other parameters like the heat capacity and the reaction enthalpies of gases are evaluated based on the theoretical values of reaction temperature. The inlet temperature, concentrations of reactants, and mass flow rates are given in the experimental conditions. The effluent composition, and outlet temperature are obtained from the experimental results. The simulation is evaluated based on the inlet condition of the experiment. Fig. 2 shows the comparison of experimental data and simulation results. The conversions of methanol decrease with increasing flow rate, which is expressed in terms of weight hourly space velocity (WHSV). The figure shows that the simulation results correlated well with experimental measurements. 
Table 2

Rate equations of the simulation

Reaction rate equation

$$
\begin{aligned}
& -r_{\text {methanol }}=k_{0, \mathrm{r}} \mathrm{e}^{-E a / R T} P_{\mathrm{CH}_{3} \mathrm{OH}}^{0.26} P_{\mathrm{H}_{2} \mathrm{O}}^{0.03} \quad\left(\text { when } P_{\mathrm{H}_{2}}<7 \mathrm{kPa}\right) \\
& \left.k_{0, \mathrm{r}} \mathrm{e}^{-E a / R T} P_{\mathrm{CH}_{3} \mathrm{OH}}^{0.26} P_{\mathrm{H}_{2} \mathrm{O}}^{0.03} P_{\mathrm{H}_{2}}^{-0.2} \quad\left(\text { when } P_{\mathrm{H}_{2}}<7 \mathrm{kPa}\right) \quad \text { (mol } / \mathrm{kg} \mathrm{s}\right)
\end{aligned}
$$

Hydrogen permeation equation

$J=\frac{\beta}{d_{\text {mem }}} A\left(\sqrt{P_{\text {reaction }}}-\sqrt{P_{\text {permeation }}}\right)$

$(\mathrm{mol} / \mathrm{s})$

$\beta=1.567 \times 10^{-5} \times \mathrm{e}^{-1011.5 / T}$

Ideal gas law for hydrogen partial pressure calculation

$\left(\mathrm{mol} /\left(\mathrm{m} \mathrm{s} \mathrm{mol} \mathrm{atm}^{1 / 2}\right)\right)$

$P_{\mathrm{H}_{2}}=C_{\mathrm{H}_{2}}$ RT

Table 3

Physical and chemical parameters of the simulation

\begin{tabular}{ll}
\hline Permeator radius $r_{1}$ & $6.35 \times 10^{-3} \mathrm{~m}$ \\
Reactor radius $r_{2}$ & $1.27 \times 10^{-2} \mathrm{~m}$ \\
Oxidation zone radius $r_{3}$ & $1.91 \times 10^{-2} \mathrm{~m}$ \\
Reactor length $L$ & $1.5 \times 10^{-1} \mathrm{~m}$ \\
Frequency factor of methanol steam & $5.307 \times 10^{9} \mathrm{~mol} /\left(\mathrm{kg} \mathrm{s} \mathrm{kPa}^{0.296}\right)$ \\
reforming $k_{0, \mathrm{r}}$ & \\
Activation energy $E a$ & $1.05 \times 10^{5} \mathrm{~J} / \mathrm{mol}$ \\
Enthalpy of methanol steam reforming & $4.9 \times 10^{4} \mathrm{~J} / \mathrm{mol}$ \\
$(298.15 \mathrm{~K}) \Delta H_{\text {ref }}$ & \\
$\begin{array}{l}\text { Enthalpy of methanol total oxidation } \\
(298.15 \mathrm{~K}) \Delta H_{\text {oxi,methanol }}\end{array}$ & $-6.76 \times 10^{5} \mathrm{~J} / \mathrm{mol}$ \\
Enthalpy of hydrogen total oxidation & $-2.41 \times 10^{5} \mathrm{~J} / \mathrm{mol}$ \\
$(298.15 \mathrm{~K}) \Delta H_{\text {oxi,hydrogen }}$ & \\
Overall heat transfer coefficient in & $15.675 \mathrm{~J} /\left(\mathrm{m}^{2} \mathrm{~s} \mathrm{~K}\right)$ \\
reactor $U_{1}$ & \\
Overall heat transfer coefficient in & $20 \mathrm{~J} /\left(\mathrm{m}^{2} \mathrm{~s} \mathrm{~K}\right)$ \\
permeator $U_{2}$ &
\end{tabular}

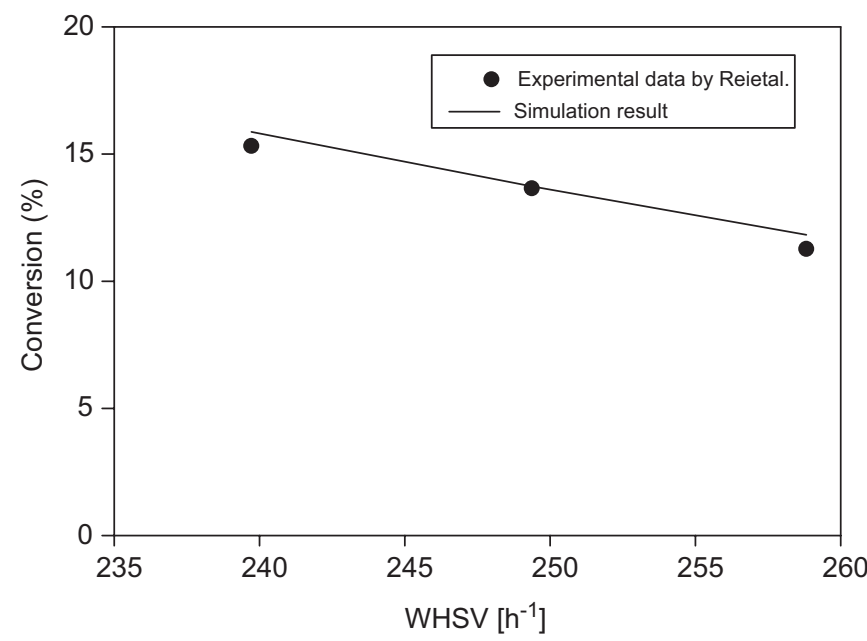

Fig. 2. Comparison of experimental data and simulation result. Reaction temperature is $583.15 \mathrm{~K}$, the constant wall temperature is $683.15 \mathrm{~K}$, and reactor pressure is $9 \mathrm{~atm}$. WHSV (weight hourly space velocity) is based on methanol mass velocity.

\subsection{Membrane reactor with oxidation zone}

As shown in Fig. 1, the double-jacketed membrane reactor is a set of three tubes. The permeation tube is in the center.



Fig. 3. The algorithm of double-jacketed membrane reactor iteration.

The reformer filled with catalysts is in the annular side of the permeation tube and is surrounded by the oxidation tube. Reactants flow into the reformer, then un-reacted methanol, steam, carbon dioxide and hydrogen are mixed with air and oxidized at the oxidation tube. To deal with this calculation, one should find out the effluent composition and concentration first; however, the composition and concentration of unreacted outlet is unknown at the beginning. As shown in Fig. 3, it is necessary to guess a set of the concentration and temperature of the effluents, then find the matched solution by iteration.

Fig. 4 presents methanol conversion versus the air to methanol molar ratio $R_{\mathrm{A} / \mathrm{M}}$ with three given air inlet temperatures. Fig. 4 shows a maximum value of methanol conversion when $R_{\mathrm{A} / \mathrm{M}}$ is about 1.3 at a given air inlet temperature. In addition, methanol conversion increases as the air inlet temperature increases. Sufficient air is necessary to supply the complete oxidation of un-reacted methanol and un-permeated hydrogen. Methanol and hydrogen are totally oxidized when $R_{\mathrm{A} / \mathrm{M}}$ is about 5 . However, high airflow rate decreases the temperature gradient between the oxidation and annular side. The trade-off between the two effects results in a maximum value of methanol conversion.

Fig. 5 shows the temperature profile in annular side versus dimensionless reactor length with three different air-to-methanol molar ratios. As shown in Fig. 5, the temperature profile first drops drastically in the front side of the reactor, and then levels off in the rear half of the reactor. Most reactants are converted in the front side of reactor because the inlet concentration and temperature are high. The temperature decreases significantly due to highly endothermic reforming when the 


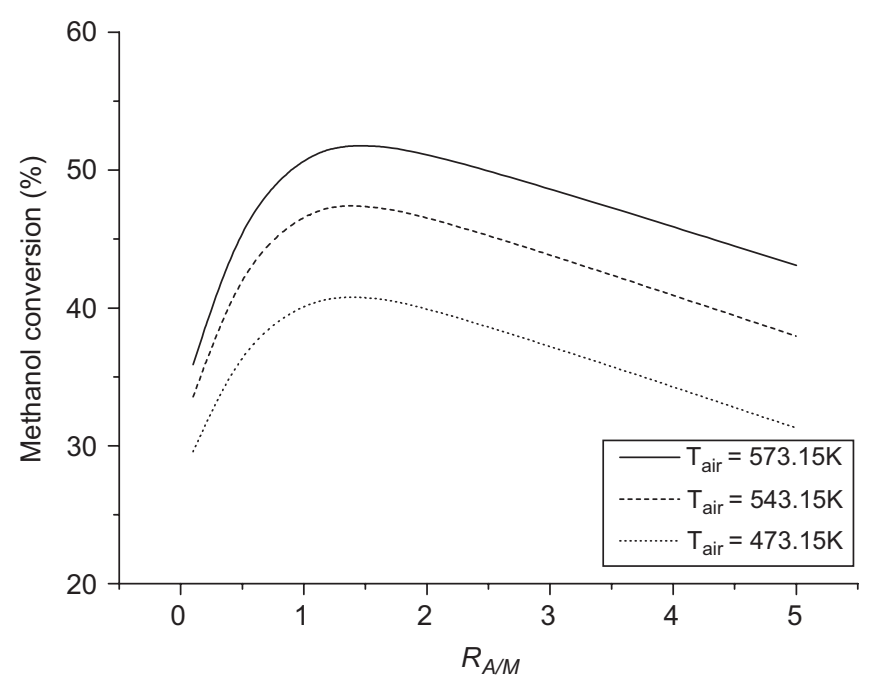

Fig. 4. Methanol conversion against $R_{\mathrm{A} / \mathrm{M}}$ with three given temperature. The reactor pressure is $9 \mathrm{~atm}, R_{\mathrm{W} / \mathrm{M}}$ is 1.2 .

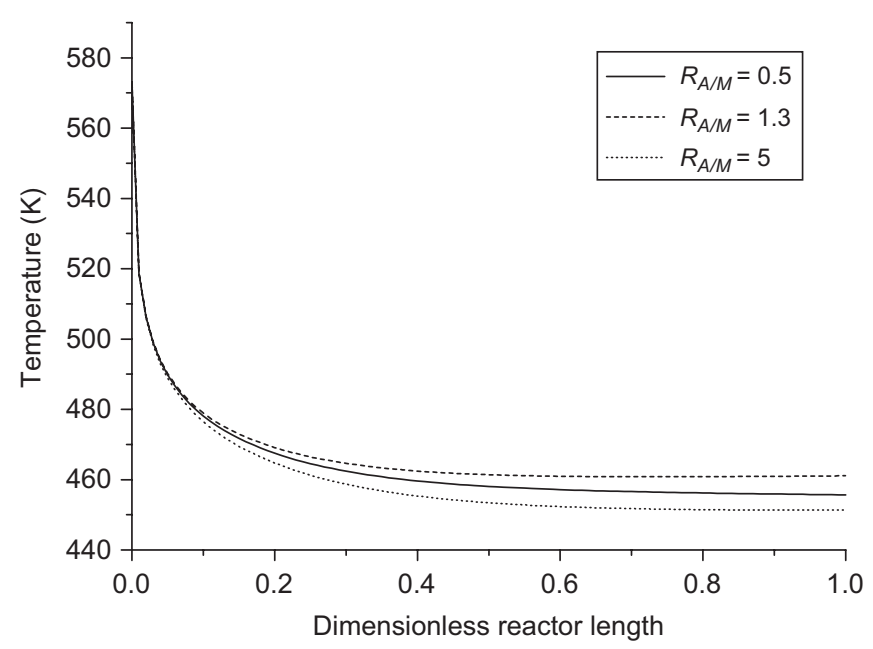

Fig. 5. Temperature profile in annular side against dimensionless reactor length with three given $R_{\mathrm{A} / \mathrm{M}}$. The reactor pressure is $9 \mathrm{~atm}$, inlet temperature is $573.15 \mathrm{~K}$, and $R_{\mathrm{W} / \mathrm{M}}$ is 1.2 .

dimensionless length is longer than 0.2. Consequently, the reaction rate decreases simultaneously. The curves of three given air-to-methanol molar ratios, $R_{\mathrm{A} / \mathrm{M}}$, also show good agreement with Fig. 4. That is, $R_{\mathrm{A} / \mathrm{M}}=1.3$ gives a higher conversion than the other two.

High methanol conversion and pure hydrogen can be obtained using the membrane. It is interesting to study the operational relations between the annular and the permeator. However, there are many factors that influence the hydrogen flow rate in the annular and permeator. It is convenient to introduce a dimensionless term Per as shown in Eq. (17), and consider the hydrogen extraction using a ratio of superficial velocity in permeator and annular as shown in Eq. (18). In real practice, the variation of this ratio can be achieved by changing the permeator pressure using a back-pressure regulator or vac-

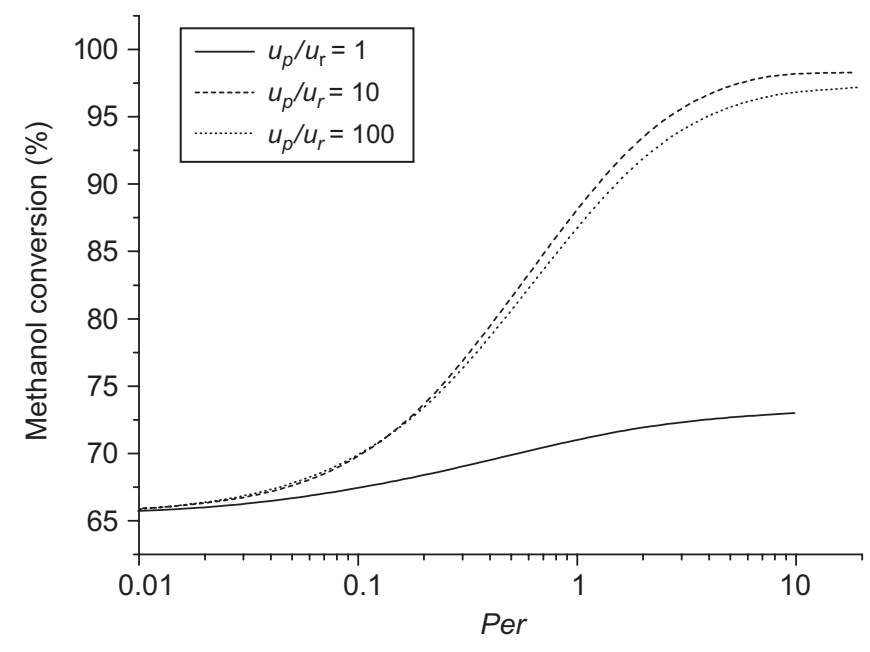

Fig. 6. Methanol conversion against the dimensionless permeability Per. The inlet temperature is $573 \mathrm{~K}$, reactor pressure is $9 \mathrm{~atm}, R_{\mathrm{W} / \mathrm{M}}$ is 1.2 , and the $R_{\mathrm{A} / \mathrm{M}}$ is 1.3 .

uum pump. Thus, the value of the ratio can be simulated in a wide range.

$$
\begin{aligned}
\text { Per } & =\frac{\mathrm{H}_{2} \text { permeation rate at the entrance }}{\text { methanol molar rate at the entrance }} \\
& =\frac{\beta / d_{\mathrm{mem}} A_{\mathrm{mem}}\left(\sqrt{P_{\mathrm{H}_{2}, \mathrm{r}}}-\sqrt{P_{\mathrm{H}_{2}, \mathrm{p}}}\right)_{z=0}}{G_{\text {methanol }, 0}}
\end{aligned}
$$

$\frac{u_{\mathrm{p}}}{u_{\mathrm{r}}}=\frac{\text { superficial velocity in permeation side }}{\text { superficial velocity in annular side }}$.

Fig. 6 shows the profile of methanol conversion versus the dimensionless permeability of hydrogen, which is evaluated by Eq. (17). The velocity ratio, $u_{\mathrm{p}} / u_{\mathrm{r}}$, is defined by Eq. (18). When $u_{\mathrm{p}} / u_{\mathrm{r}}$ is large, the hydrogen velocity in permeation side is much higher than that in annular side, that is, hydrogen is removed in permeation side as fast as possible. The more the hydrogen removed in permeation side, the higher the difference of hydrogen partial pressure between the annular and permeation sides. Therefore, the difference of hydrogen partial pressure increases as $u_{\mathrm{p}} / u_{\mathrm{r}}$ increases.

The hydrogen permeation is affected by temperature, membrane thickness, membrane surface area, and the difference of hydrogen pressure between the annular and permeation sides. High permeation rate can be operated under high temperature, short membrane depth, large membrane surface area, or high pressure difference between the annular and permeation side. As shown in Fig. 6, when Per is under 0.02, methanol conversion is almost the same in three different $u_{\mathrm{p}} / u_{\mathrm{r}}$. Increasing the difference of hydrogen partial pressure is not helpful for the methanol conversion because only a small amount of hydrogen permeates into the permeation side. The methanol conversion starts to have a huge difference between $u_{\mathrm{p}} / u_{\mathrm{r}}=1$ and 10 when Per is larger than 0.1 . The hydrogen removal to permeation side decreases the hydrogen pressure in reaction side, and thus drives the methanol reforming toward the products 


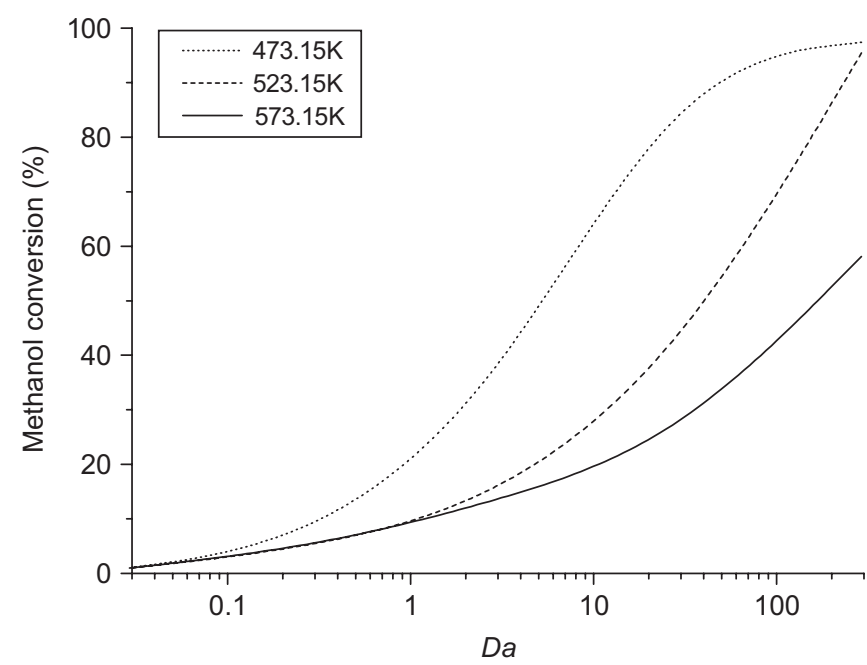

Fig. 7. Methanol conversion against $D a$ with different temperature. The reactor pressure is $9 \mathrm{~atm}, R_{\mathrm{W} / \mathrm{M}}$ is 1.2 , and the $R_{\mathrm{A} / \mathrm{M}}$ is 1.3 .

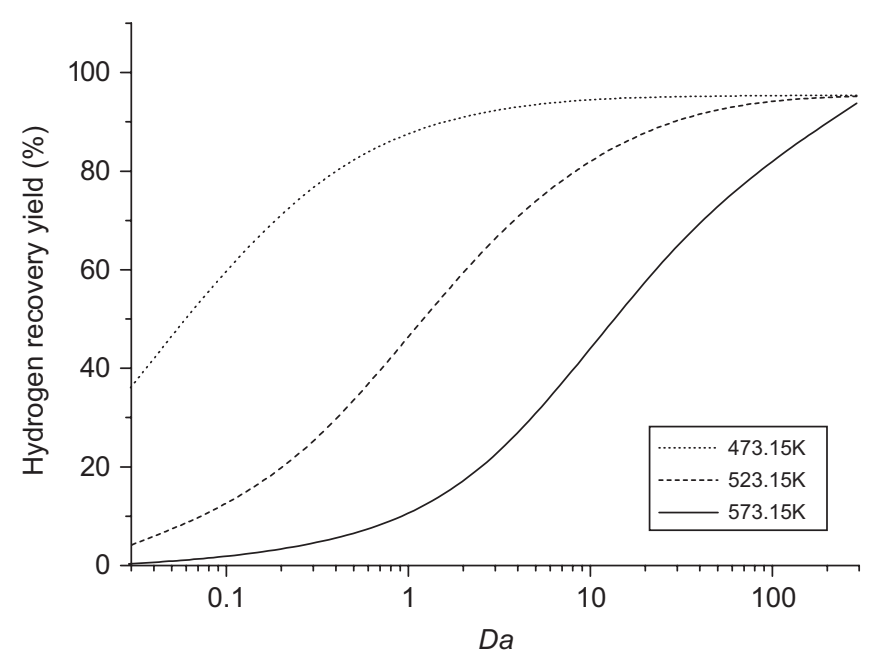

Fig. 8. Hydrogen recovery yield against $D a$ with different temperature. The reactor pressure is $9 \mathrm{~atm}, R_{\mathrm{W} / \mathrm{M}}$ is 1.2 , and the $R_{\mathrm{A} / \mathrm{M}}$ is 1.3 .

of Eq. (1) resulting in more methanol conversion. However, the methanol conversion of $u_{\mathrm{p}} / u_{\mathrm{r}}=100$ is slightly less than that of $u_{\mathrm{p}} / u_{\mathrm{r}}=10$ when Per is larger than 0.2. First, the enthalpy of hydrogen moves to the permeation side as hydrogen permeates through the membrane. Second, un-reacted methanol and unpermeated hydrogen are supposed to be oxidized to maintain the reactor self-energy balance. When $u_{\mathrm{p}} / u_{\mathrm{r}}=100$, the oxidation of un-permeated hydrogen may not be enough to supply heat to sustain the endothermic reaction of high methanol conversion.

The rate of methanol steam reforming is a function of inlet temperature. Figs. 7-9 show methanol conversion, the hydrogen recovery yield, and the production rate of hydrogen versus Damköhler $(D a)$ number, respectively, under three different inlet temperatures. The $D a$ number is the ratio of

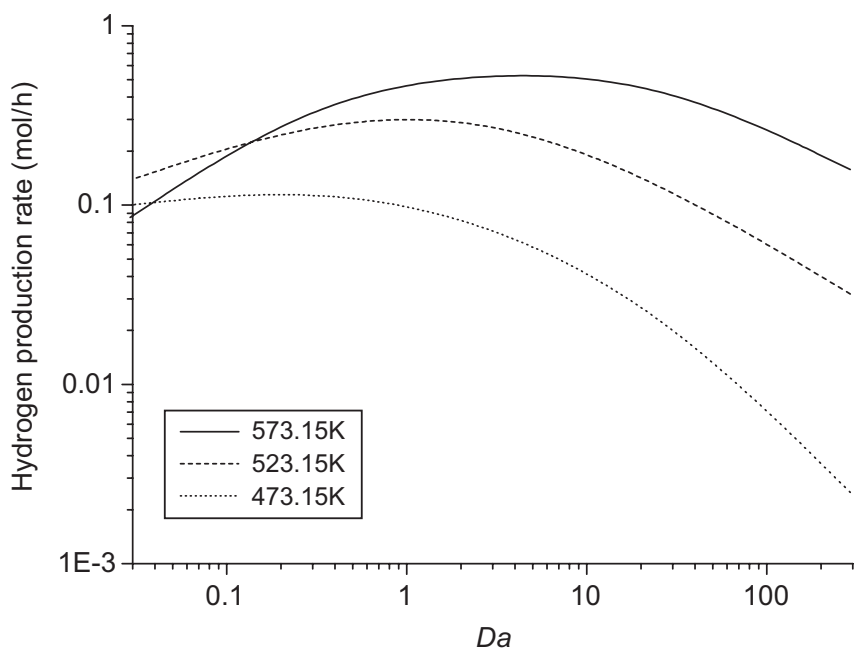

Fig. 9. Hydrogen production rate against $D a$ with different temperature. The reactor pressure is $9 \mathrm{~atm}, R_{\mathrm{W} / \mathrm{M}}$ is 1.2 , and the $R_{\mathrm{A} / \mathrm{M}}$ is 1.3 .

methanol reforming rate and flow rate, which is defined as

$$
\begin{aligned}
D a & =\frac{\text { methanol steam reforming rate at the entrance }}{\text { methanol molar rate at the entrance }} \\
& =\frac{\rho_{\mathrm{B}}\left(-r_{\text {methanol }, 0}\right)}{G_{\text {methanol, } 0}} .
\end{aligned}
$$

In Fig. 7, when $D a$ is less than 0.1, the methanol conversions of three inlet temperatures are low and almost the same. Increasing temperature is not helpful to enhance methanol conversion because the methanol flow rate is very high compared with reforming rate. When $D a$ is larger than 0.1, the methanol conversion decreases as reaction temperature increases at any given $D a$ number. Although the reforming rate at high temperature is higher than that at low temperature, the methanol flow rate at high temperature is also higher than that at low temperature at a fixed Damköhler number. That is, the residence time at high temperature is smaller than that at low temperature. Therefore, the methanol conversion at low temperature becomes higher than that at high temperature because reforming is carried on for a longer time in the reactor at the low temperature. Although high methanol conversion can be obtained at low temperature, it costs a larger Pd membrane reactor under the same throughput of methanol.

The recovery yield of hydrogen is the percentage of pure hydrogen that can be collected from the total hydrogen generation as shown in Eq. (20). As shown in Fig. 8, the tendency of the hydrogen recovery yield is similar to methanol conversion in Fig. 7. According to Sievert's law, hydrogen permeation rate is proposed to the difference of the square root of hydrogen partial pressure through Pd membrane. The increasing of $D a$ number leads to higher methanol conversion and hydrogen permeation. At a fixed $D a$ number, the hydrogen recovery yield increases as reaction temperature decreases. The reason is the same as methanol conversion. That is, the residence time of low temperature is higher than that of high temperature. The amount of hydrogen permeation increases increasing the 
residence time at the low temperature, but at the cost of larger Pd surface area.

$\mathrm{H}_{2}$ recovery yield

$$
\begin{aligned}
& \frac{\mathrm{H}_{2} \text { collected in the permeation side }}{\text { total amount of } \mathrm{H}_{2} \text { generated by reforming reaction }} \\
& \times 100 \% \text {. }
\end{aligned}
$$

Fig. 9 shows maximum hydrogen production rates at three inlet temperatures. The hydrogen production rate is the mole of hydrogen collected per hour at the end of permeation tube. A high $D a$ number can mean either high methanol reforming rate or low feed rate. The hydrogen production rate is leverage between methanol conversion and feed rate. When the temperature is $573.15 \mathrm{~K}$, the maximum value of hydrogen production rate occurs at $D a$ near 5 . The optimum condition can be operated at $D a$ ranging from 1 to 10 . For a given reactor volume, the feed rate (methanol) is too small to get a high hydrogen production rate at $D a>10$ although the conversion is high (Fig. 7). The conversion is too low to get a high hydrogen production rate at $D a<1$ although the feed rate is high.

Fig. 9 also shows that the hydrogen production rate increases as temperature increases when $D a$ is larger than 0.2 , while the trend is reverse when $D a$ is less than 0.2. The elevation of temperature promotes the reforming reaction and hydrogen permeation when it is operated at $D a>0.2$. However, at $D a<0.2$, more hydrogen permeation is at low temperature than that high temperature because of the longer residence time at low temperature.

The maximum hydrogen production rate does not imply high recovery yield. For instance, when the inlet temperature is $523.15 \mathrm{~K}$, the maximum hydrogen production rate is $0.3 \mathrm{~mol} / \mathrm{h}$ at $D a=1$ (Fig. 9), whereas the recovery yield is only $\sim 40 \%$ (Fig. 8). The hydrogen recovery yield has to be decreased if a high production rate is desired. That is, the faster you get hydrogen, the less you will obtain.

\subsection{The comparison between double-jacketed and autothermal membrane reactor}

The concept of the autothermal reactor is that pure oxygen or air is directed into the reformer to oxidize part of reactants for self-energy balance. Reforming and oxidizing in one reactor facilitate the enthalpy generated by oxidation transferring to reforming reaction, and thus avoids the thermal resistance from outside furnace combustion like double-jacketed reactor. However, a catalyst with good reforming ability may not be good for oxidation. Take $\mathrm{CuO} / \mathrm{ZnO} / \mathrm{Al}_{2} \mathrm{O}_{3}$ as an example; the total oxidation of methanol can be expressed in Eq. (21). The rate expression of methanol total oxidation over $\mathrm{CuO} / \mathrm{ZnO} / \mathrm{Al}_{2} \mathrm{O}_{3}$ is shown in Eq. (22) [44]. The methanol oxidation rate over catalyst $\mathrm{CuO} / \mathrm{ZnO} / \mathrm{Al}_{2} \mathrm{O}_{3}$ is much smaller than traditional oxidation catalyst such as $\mathrm{Pt} / \mathrm{Al}_{2} \mathrm{O}_{3}$ or $\mathrm{Pd} / \mathrm{Al}_{2} \mathrm{O}_{3}$.

$$
\begin{gathered}
\mathrm{CH}_{3} \mathrm{OH}+1.5 \mathrm{O}_{2} \rightarrow \mathrm{CO}_{2}+2 \mathrm{H}_{2} \mathrm{O}, \\
\Delta H_{298 \mathrm{~K}}=676.4 \mathrm{KJ} / \mathrm{mol},
\end{gathered}
$$

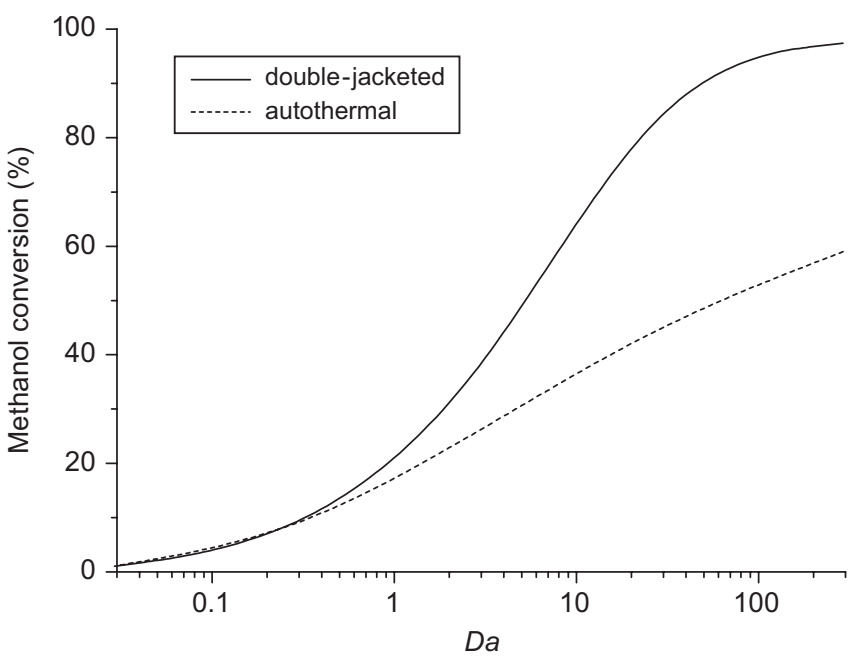

Fig. 10. Methanol conversion against $D a$ of double-jacketed and autothermal reactor. The inlet temperature is $473.15 \mathrm{~K}$, reactor pressure is $9 \mathrm{~atm}, R_{\mathrm{W} / \mathrm{M}}$ is 1.2 , and the $R_{\mathrm{A} / \mathrm{M}}$ is 1.3 .

$$
\begin{aligned}
-r_{\text {oxi, methanol }}= & 3.6 \times 10^{9} \times \mathrm{e}^{-\frac{115000}{R T}} \frac{P_{\text {methanol }}^{0.18} \cdot P_{\text {oxygen }}^{0.18}}{P_{\text {water }}^{0.14}} \\
& \times\left(\mathrm{mol} /\left(\mathrm{s} \mathrm{g}_{\text {cat }} \mathrm{kPa}^{0.22}\right)\right) .
\end{aligned}
$$

Fig. 10 shows the methanol conversion against $D a$ number of double-jacketed and autothermal membrane reactor using $\mathrm{CuO} / \mathrm{ZnO} / \mathrm{Al}_{2} \mathrm{O}_{3}$ catalyst. As shown in Fig. 10, when $D a$ is under 0.4 , the methanol conversion of double-jacketed reactor is almost the same as that of autothermal reactor. This trend indicates that the reactor type is not an important factor when $D a$ is less than 0.4. At the small $D a$ number region, the methanol flow rate is relatively higher than reforming rate, thus heating from outside (double-jacketed reactor) or inside (autothermal reactor) does not make a difference of the methanol conversion. When $D a$ is larger than 1, the methanol conversion of doublejacketed reactor becomes higher than that of autothermal reactor. This result reveals that, in the reaction-dominating region ( $D a>1)$, the double-jacketed reactor outperforms autothermal reactor. Under the same reaction conditions (inlet temperature, pressure, water to methanol molar ratio, and air to methanol molar ratio), the air dilutes the reactant concentration in annular side of the autothermal reactor resulting in a lower reaction rate of autothermal reactor than double-jacketed reactor. Consequently, the methanol conversion of autothermal reactor is less than that of double-jacketed reactor.

Fig. 11 presents the hydrogen recovery yield and production rate versus $D a$ number in autothermal and double-jacketed reactors, respectively. The hydrogen production rate of doublejacketed reactor is always higher than that of autothermal reactor in full $D a$ range. The hydrogen recovery yield of double-jacketed reactor is higher than that of autothermal reactor when $D a$ is smaller than 2, and vice versa when $D a$ is larger than 2. Under a given reaction pressure, the diluted effect of autothermal reactor decreases the hydrogen partial pressure, thus the hydrogen permeation rate of autothermal reactor is 


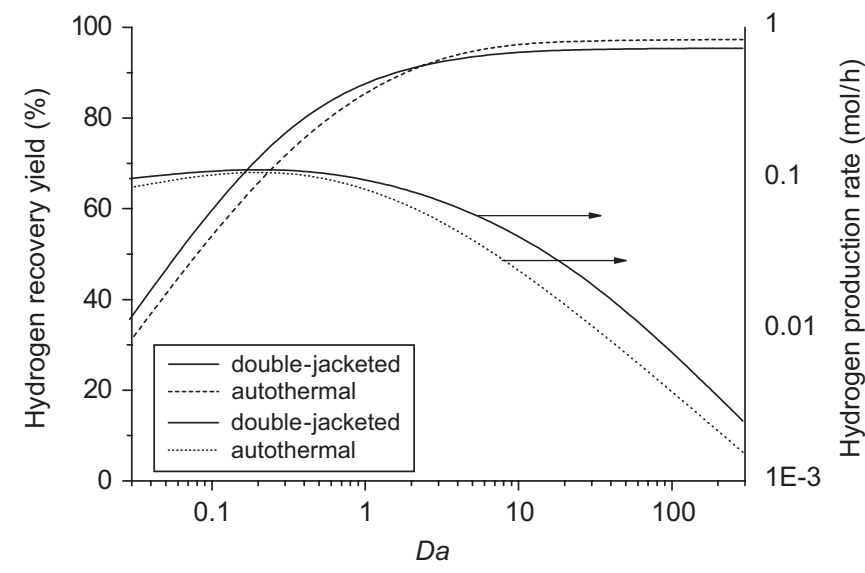

Fig. 11. Recovery yield and production rate of hydrogen against $D a$ of double-jacketed and autothermal reactor. The inlet temperature is $473.15 \mathrm{~K}$, reactor pressure is $9 \mathrm{~atm}, R_{\mathrm{W} / \mathrm{M}}$ is 1.2 , and the $R_{\mathrm{A} / \mathrm{M}}$ is 1.3 .

lower than that of double-jacketed reactor. Consequently, the hydrogen recovery yield of autothermal reactor is lower than that of double-jacketed reactor. The same situation is also shown in the hydrogen production rate. However, when $D a$ is larger than 2, the conversion of double-jacketed reactor becomes much higher than that of autothermal reactor as shown in Fig. 10. Thus, the total amount of hydrogen (i.e. annular side and permeation side) of the double-jacketed reactor is much higher than that of autothermal reactor. However, the hydrogen recovery yield is defined as the amount of hydrogen in permeation side dividing by the amount of hydrogen produced (Eq. (20)). For the double-jacketed reactor, the increment of denominator (total amount of hydrogen produced) is higher than that of numerator (the recovered hydrogen from permeation). Thus, the hydrogen recovery yield of double-jacketed reactor is slightly less than that of autothermal reactor when $D a$ is larger than 2 .

\section{Conclusions}

In this study, a 1-D mathematical model of double-jacketed reactor is established to simulate a self-sustained doublejacketed reactor. It is found that an optimum velocity ratio between permeation and annular sides is of at the order of 10 because of the hydrogen and enthalpy removing simultaneously. In addition, at a given $D a$ number, the methanol conversion and hydrogen recovery yield decreases as temperature increases, while the hydrogen production rate increases as temperature increases. The optimum air to methanol molar ratio $R_{\mathrm{A} / \mathrm{M}}$ is about 1.3 , though the required $R_{\mathrm{A} / \mathrm{M}}$ to completely oxidize methanol and hydrogen is about 5 . High $R_{\mathrm{A} / \mathrm{M}}$ leads to high methanol and hydrogen conversion and high flow rate of air in oxidation zone. The competition effect of oxidation and methanol flow rate leads to the optimum value of $R_{\mathrm{A} / \mathrm{M}}$. Under the same reaction conditions (inlet temperature, pressure, water to methanol molar ratio, and air to methanol molar ratio), double-jacketed reactor gives better performance than autothermal reactor.

\section{Acknowledgment}

The authors thank Dr. Min-Hon Rei of the Green Hydrotec, Taiwan, for providing the experimental results of methanol reforming in $\mathrm{Pd}$ membrane reactor.

\section{References}

[1] Uemiya S, Matsuda T, Kikuchi E. Hydrogen permeable palladium silver alloy membrane supported on porous ceramics. J Membr Sci 1991;56(3):315-25.

[2] Uemiya S, Sato N, Ando H, Matsuda T, Kikuchi E. Steam reforming of methane in a hydrogen-permeable membrane reactor. Appl Catal 1991;67(2):223-30.

[3] Uemiya S, Sato N, Ando H, Kude Y, Matsuda T, Kikuchi E. Separation of hydrogen through palladium thin-film supported on a porous-glass tube. J Membr Sci 1991;56(3):303-13.

[4] Collins JP, Way JD. Preparation and characterization of a composite palladium-ceramic membrane. Ind Eng Chem Res 1993;32(12): 3006-13.

[5] Kikuchi E. Palladium/ceramic membranes for selective hydrogen permeation and their application to membrane reactor. Catal Today 1995;25(3-4):333-7.

[6] Lin YM, Lee GL, Rei MH. An integrated purification and production of hydrogen with a palladium membrane-catalytic reactor. Catal Today 1998;44(1-4):343-9.

[7] Jiang CJ, Trimm DL, Wainwright MS. Kinetic-study of steam reforming of methanol over copper-based catalysts. Appl Catal A 1993;93(2): 245-55.

[8] Jiang CJ, Trimm DL. Wainwright MS. Kinetic mechanism for the reaction between methanol and water over a $\mathrm{Cu}-\mathrm{ZnO}-\mathrm{Al} 2 \mathrm{O} 3$ catalyst. Appl Catal A $1993 ; 97(2): 145-58$

[9] Peppley BA, Amphlett JC, Kearns LM, Mann RF. Methanol-steam reforming on $\mathrm{Cu} / \mathrm{ZnO} / \mathrm{Al} 2 \mathrm{O} 3$. Part 1: the reaction network. Appl Catal A $1999 ; 179(1-2): 21-9$.

[10] Peppley BA, Amphlett JC, Kearns LM, Mann RF. Methanol-steam reforming on $\mathrm{Cu} / \mathrm{ZnO} / \mathrm{Al} 2 \mathrm{O} 3$ catalysts. Part 2: a comprehensive kinetic model. Appl Catal A 1999;179(1-2):31-49.

[11] Itoh N. A membrane reactor using palladium. AIChE J 1987;33(9): 1576-8.

[12] Mohan K, Govind R. Effect of temperature on equilibrium shift in reactors with a permselective wall. Ind Eng Chem Res 1988;27(11): 2064-70.

[13] Itoh N, Govind R. Combined oxidation and dehydrogenation in a palladium membrane reactor. Ind Eng Chem Res 1989;28(10):1554-7.

[14] Lin YM, Rei MH. Process development for generating high purity hydrogen by using supported palladium membrane reactor as steam reformer. Int J Hydrogen Energy 2000;25(3):211-9.

[15] Lin YM, Rei MH. Separation of hydrogen from the gas mixture out of catalytic reformer by using supported palladium membrane. Sep Purif Tech 2001;25(1-3):87-95.

[16] Lin YM, Rei MH. Study on the hydrogen production from methanol steam reforming in supported palladium membrane reactor. Catal Today 2001;67(1-3):77-84.

[17] Lindstrom B, Pettersson LJ. Development of a methanol fuelled reformer for fuel cell applications. J Power Sources 2003;118(1-2):71-8.

[18] Jenkins JW, Shutt E. Hydrogen generation using a novel concept. Platinum Met Rev 1989;33:118-27.

[19] Hohlein B, Boe M, Bogild-Hansen J, Brockerhoff P, Colsman G, Emonts B. et al. Hydrogen from methanol for fuel cells in mobile system: development of a compact reformer. J Power Sources 1996;61(1-2): 143-7.

[20] Pena MA, Gomez JP, Fierro JLG. New catalytic routes for syngas and hydrogen production. Appl Catal A 1996;144(1-2):7-57.

[21] Geissler K, Newson E, Vogel F, Truong TB, Hottinger P, Wokaun A. Autothermal methanol reforming for hydrogen production in fuel cell applications. Phys Chem Chem Phys 2001;3(3):289-93. 
[22] Mizsey P, Newson E, Truong TB, Hottinger P. The kinetics of methanol decomposition: a part of autothermal partial oxidation to produce hydrogen for fuel cells. Appl Catal A 2001;213(2):233-7.

[23] Yong ST, Hidajat K, Kawi S. Reaction study of autothermal steam reforming of methanol to hydrogen using a novel nano $\mathrm{CuZnAl}$ catalyst. J Power Sources 2004;131(1-2):91-5.

[24] Choudhary VR, Mondal KC, Mamman AS. High-temperature stable and highly active/selective supported $\mathrm{NiCoMgCeO}$ catalyst suitable for autothermal reforming of methane to syngas. J Catal 2005;233(1):36-40.

[25] Koga H, Fukahori S, Kitaoka T, Tomoda A, Suzuki R, Wariishi H. Autothermal reforming of methanol using paper-like $\mathrm{Cu} / \mathrm{ZnO}$ catalyst composites prepared by a papermaking technique. Appl Catal A 2006;309(2):263-9.

[26] Rampe T, Heinzel A, Vogel B. Hydrogen generation from biogenic and fossil fuels by autothermal reforming. J Power Sources 2000;86(1-2): 536-41.

[27] Palm C, Cremer P, Peters R, Stolten D. Small-scale testing of a precious metal catalyst in the autothermal production of ultrapure hydrogen. J Power Sources 2002;106(1-2):231-7.

[28] Semelsberger TA, Brown LF, Borup RL, Inbody MA. Equilibrium product from autothermal processes for generating hydrogen-rich fuel cell feeds. Int J Hydrogen Energy 2004;29(10):1047-64.

[29] Cavallaro S, Freni S. Syngas and electricity production by an integrated autothermal reforming/molten carbonate fuel cell system. J Power Sources 1998;76(2):190-6.

[30] Reuse P, Renken A, Haas-Santo K, Gorke O, Schubert K. Hydrogen production for fuel cell application in an autothermal micro-channel reactor. Chem Eng J 2004;101(1-3):133-41.

[31] Chan SH, Wang HM. Thermodynamic and kinetic modelling of an autothermal methanol reformer. J Power Sources 2004;126(1-2):8-15.

[32] Grace JR, Li X, Lim CJ. Equilibrium modeling of catalytic steam reforming of methane in membrane reactor with oxygen addition. Catal Today 2001;64(3-4):141-9.
[33] Lattner JR, Harold MP. Comparison of conventional and membrane reactor fuel processors for hydrocarbon-based PEM fuel cell system. Int J Hydrogen Energy 2004;29(4):393-417.

[34] Hoang DL, Chan SH. Modelling of a catalytic autothermal methane reformer for fuel cell applications. Appl Catal A 2004;268(1-2):207-16.

[35] Lattner JR, Harold MP. Comparison of methanol-based fuel processors for PEM fuel cell systems. Appl Catal B 2005;56(1-2):149-69.

[36] Harold MP, Nair B, Kolios G. Hydrogen generation in a Pd membrane fuel processor: assessment of methanol-based reaction systems. Chem Eng Sci 2003;58(12):2551-71.

[37] Ji P, van der Kooi HJ, Arons JD. Simulation and thermodynamic analysis of an integrated process with $\mathrm{H}-2$ membrane $\mathrm{CPO}$ reactor for pure $\mathrm{H}-2$ production. Chem Eng Sci 2003;58(17):3901-11.

[38] Fukuhara C, Igarashi A. Two-dimensional simulation of a membrane reactor for dehydrogenation of ethylbenzene, considering heat and mass transfer. J Chem Eng Jpn 2003;36(5):530-9.

[39] Kawamura Y, Ogura N, Yahata T, Yamamoto K, Terazaki T, Yamamoto T. et al. Multi-layered microreactor system with methanol reformer for small PEMFC. J Chem Eng Jpn 2005;38(10):854-8.

[40] Specchia S, Cutillo A, Saracco G, Specchia V. Concept study on ATR and SR fuel processors for liquid hydrocarbons. Ind Eng Chem Res 2006;45(15):5298-307.

[41] Fahien RW, Smith JM. Mass transfer in packed beds. AIChE J 1955;1(1):28-37.

[42] Froment GF, Bischoff KB. Chemical reactor analysis and design. New York: Wiley; 1990.

[43] Pan CW. The kinetics study of methanol steam reforming reaction using palladium membrane reactor. Master thesis, Chang Gung University; 2003.

[44] Reitz TL, Ahmed S, Krumpelt M, Kumar R, Kung HH. Characterization of $\mathrm{CuO} / \mathrm{ZnO}$ under oxidizing conditions for the oxidative methanol reforming reaction. J Mol Catal A 2000;162(1-2):275-85. 